\title{
Research and Practice of "Advanced Mathematics" Gold Course Construction in the Information Age \\ Tingyong Deng"
}

\author{
College of Science, Heilongjiang Bayi Agricultural University, Daqing163319, China
}

DOI: $10.36347 /$ sipms.2020.v07i07.003

| Received: 01.07.2020 | Accepted: 09.07.2020 | Published: 18.07.2020

*Corresponding author: Tingyong Deng

Abstract

Higher mathematics courses have a high degree of abstraction, rigorous reasoning, and extensive application. It is feasible and necessary to create a "gold course" in advanced mathematics courses, and it is an excellent carrier for the challenge of "gold course". As one of the compulsory courses, higher mathematics courses in colleges and universities have become an important issue in higher education. Through an in-depth analysis of the background of the information age, this paper proposes a "golden class" model to improve students' enthusiasm, interactivity, and initiative, improve students' knowledge absorption efficiency, and enable students to adapt to new industries more effectively.

Keywords: Higher mathematics, gold course, information age.

Copyright @ 2020: This is an open-access article distributed under the terms of the Creative Commons Attribution license which permits unrestricted use, distribution, and reproduction in any medium for non-commercial use (NonCommercial, or CC-BY-NC) provided the original author and source are credited.

\section{INTRODUCTION}

With the advent of the information age, many emerging industries such as artificial intelligence, intelligent robots, the Internet of Things, cloud computing, and big data have become social waves, the higher mathematics of traditional subjects is biased towards theoretical derivation, and this type of major has been difficult to meet the needs of the society for talents in this era. The traditional teaching model is out of touch with economic and social development. Talent training focuses more on teaching students how to solve engineering problems, engineering practices and teamwork, while the new industry focuses more on personal quality, social capabilities, practical experience and time management models. The concept of talent training is partially out of touch with actual needs. Today's education has problems such as a single teaching model, incomplete educational concepts, and unprofessional disciplines. In the undergraduate education work conference of Chinese colleges and universities, the concept of constructing innovative and challenging "Gold Classes" and eliminating "Water Classes" was proposed. "Water lesson" is a classroom that teachers do not care about preparing. "Golden lesson" is a fusion of knowledge, ability and literacy. Not only to train students to acquire knowledge and train logical thinking, but also to guide students to be positive and learn innovative thinking. However, there are many problems in the traditional curriculum teaching, which requires us to explore reform and improvement. Therefore, in line with the information age, building a "golden class" suitable for students in this era has become the primary task of educational reform $[1,2]$.

The Necessity of Teaching "Gold Class" of Advanced Mathematics in the Information Age

Faced with the development needs under the new economic situation, college mathematics majors are closely related to artificial intelligence, big data, 5G Internet of Things and other majors. The neural network algorithm derivation process in the deep learning course requires deep mathematical logic derivation, and the basis for the flexible use of computer algorithms is the completion of mathematical theory. Therefore, the current mathematics courses in colleges and universities should take into account the professional needs of the later period, and analyze the combination of industry characteristics, humanistic characteristics and national humanistic literacy, so that the college mathematics courses in the information age have the leading and international integration of the times.

College mathematics curriculum models should be diversified, not limited to forms, introducing novel models such as flipping courses, special education classrooms, and tea party classrooms to improve students' motivation in the classroom. The 
distance between teachers and students is shortened through the exchange of roles between students and teachers. The best mode of learning is discussion. Higher mathematics is a big mountain for some students. It is not easy to learn, but it is even more difficult to teach well. Classes are no longer limited to the dissemination of mathematical knowledge, but also need to insert the acquisition of humanistic knowledge, such as the source of mathematical theoretical knowledge, astronomy and geography, celebrity biographies, or the story of the growth of mathematicians, making all kinds of hard math formulas interesting. The spread of this cultural heritage can enhance students' personal qualities. What they learn from these stories is not only mathematical knowledge, but also a research attitude.

In the teaching of higher mathematics, it is necessary to activate students' original experience and connect with new knowledge. For example, "curve area" and "rectangle area" have inherent similarity, "curve area is divided into small rectangles and then accumulate" and "circular area seeking method" have inherent similarity, so that students are more easily accepted. Therefore, activating the original experience and establishing a connection with new knowledge is the rule of creating a "golden lesson" in advanced mathematics. The enrichment of mathematics classrooms in colleges and universities is an inspiration to education, which makes traditional logical classrooms a "golden class" in the information age, enriching classrooms, giving students a sense of gain, and making teachers more professional.

"Gold class" is the best choice for creating high-quality university mathematics classrooms in the information age and cultivating high-quality college students. Cultivating students' learning ability, thinking ability, communication ability, cooperation ability, positive emotions, and good quality is far more important than learning knowledge itself. These requirements can be well realized through the "golden class" of advanced mathematics. Higher mathematics "gold courses" in the information age can effectively improve the quality of teaching, and provide strong support for my country's higher education from scale expansion to connotative development, building a strong education country, and realizing the great rejuvenation of the Chinese nation.

Problems in higher mathematics "gold class" teaching in the information age

With the extensive use of modern information technology in education and teaching, the continuous integration of information technology and education and teaching technology, "Internet + education" has spawned a new class, namely online teaching, online teaching platforms have sprung up and developed vigorously. The online teaching of "Advanced Mathematics" has also gradually developed into a new form of "Higher Mathematics" classroom teaching, but there are the following problems:

\section{Teachers lag behind}

Today, when information technology is widely used in education and teaching, some "advanced mathematics" teachers are conservative in their thoughts, and their teaching concepts cannot keep up with the times. They are outdated in the new era of "higher mathematics" teaching reform. There are also some "Higher Mathematics" teachers who lack the literacy of modern information technology, do not master basic modern information teaching technology, do not make courseware and videos, do not understand online teaching platforms, and do not even use new social media.

\section{Students have weak autonomous learning ability}

Because college students have been in the traditional classroom teaching environment for a long time, many college students have become accustomed to "stretching hands to get clothes, meals to open mouth". The ability of self-learning online courses is poor, and the ability of self-control is insufficient. The students will only passively accept the learning tasks assigned by teachers and use traditional learning methods without timely adjusting his physical and mental state. Today, the students are well versed in modern electronic products, but they have poor awareness of using electronic products for online classroom learning. They are not interested in online teaching and spend a lot of energy on chatting, entertainment, games, Online shopping, etc., wasted resources. Due to the lack of correct guidance to them, the online teaching of "Higher Mathematics" is not satisfactory.

The construction standard of the "gold course" of higher mathematics in the information age

To build a "gold course" for higher mathematics, it is necessary to understand the standards for the construction of the "gold course". Wu Yan proposed that the "golden class" should reflect "one degree of both sexes": high order, innovation and challenge. However, the goals and requirements of each subject and each course are different, so the standard of the "gold course" cannot be completely unified. For the "Gold Course" of "Advanced Mathematics" online, there are mainly the following standards:

1. The "golden class" of higher mathematics should insist on establishing morality, ethics of teachers, ability of educating people should be strong, the content of ideological and political education should be scientifically and rationally designed, and the education of socialist core values should be integrated into all aspects of online teaching. Teachers have a high level of online teaching and possess good information technology and literacy.

2. The "golden course" of higher mathematics should embody the fusion of information technology and 
"higher mathematics". The content of the course should be innovative and challenging, reflect the times and cutting-edge, and reflect the latest development and application of educational technology. Online content should be updated and improved in time. The online platform is easy to operate and rich in resources, suitable for students to learn.

3. The "golden course" of higher mathematics should embody "student-centered" and promote the comprehensive development of students. The teaching method should be scientific and reasonable, conform to the law of education and teaching, and reflect the advanced and interactive nature. With students as the center, establish a new type of teaching relationship and adopt group, autonomous and collaborative learning. Teaching activities are inquisitive and personalized, cultivating critical thinking, innovative thinking and the ability to solve complex problems.

4. Higher mathematics "gold courses" must have a reasonable assessment mechanism, and establish an online sign-in system for students. Strengthen the management of students' learning process, and strict process assessment. Online test questions should reflect openness, non-standard answers, and personalized assessments, and examine students' application and innovation abilities.
The construction of "golden courses" in higher mathematics under the background of information age requires the efforts of generations of educators. Education should reflect the times, guidance, innovation, and development. Innovation comes from course design and teacher guidance. Therefore, each course of mathematics in colleges and universities has a scientific and effective implementation plan for teaching, learning, examination and evaluation. Gradually form curriculum standards, gradually build mathematics gold courses. Guide students to become the newcomers of the times who think independently, dare to criticize, dare to question, have innovative capabilities and innovative thinking.

Subject number: GJB1320234.

Subject name: Heilongjiang Provincial Education Science "Thirteenth Five-Year Plan" Key Issues in 2020. Research Results of the 13th Five-Year Plan of Education Science in Heilongjiang Province.

\section{REFERENCE}

1. Xinjun, J. (2012). Practice and Exploration of the Construction of Excellent Course of Advanced Mathematics. Industry and Technology Forum. (18):185-186.

2. Weixun, L., \& Limin, S. (2015). Discussion on the Construction of Excellent Resources Sharing Course of Advanced Mathematics. Education Teaching Forum. (10):202-203. 